UNIVERSITY OF CAMBRIDGE

DEPARTMENT OF

APPLIED ECONOMICS

OCCASIONAL PAPER 41

\section{Exporting Workers: The Turkish Case}

SUZANNE PAINE

This new study examines the effects on the Turkish economy of the selection of labour export on a temporarily recruited basis as a major strategy, and incorporates new material from a recent survey to compile the most comprehensive picture yet available of the Turkish migrant worker. Against a background of migrant labour movements in postwar Europe, the author surveys Turkey's experience since 1960 and assesses the effects of the migration on Turkey's development.

Forthcoming (late 1974)

Paper covers about $\mathbf{f 2 . 5 0}$ net

\section{Mapai in Israel}

Political Organization and Government in a New Society PETER MEDDING

The most comprehensive account of the dominating institution of Israeli politics, the Israeli labour party. In analyzing the structure and function of Mapai, Dr Medding has made an important contribution to the understanding of contemporary Israel as a whole.

$£ 4.80$ net

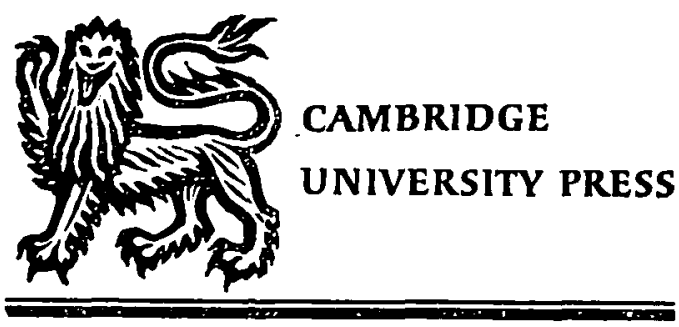

Int. Jnl. of Middle East Studies, 5, 3
Decisions in

Israel's Foreign

Policy

\section{Michael Brecher}

In this companion volume to The Foreign Policy System of Israel, which won the Woodrow Wilson Foundation Book Award for 1973, Professor Brecher analyses the decision-making process and feedback consequences of seven major foreign policy issues. In his concluding chapter he breaks new ground in an exercise to test some fifty hypotheses about how states behave. $\mathfrak{A 9}$

\section{Politics and \\ Change in \\ Al-Karak, Jordan}

A Study of a Small Arab Town and its District

\section{Peter Gubser}

This book analyses the political structure and power relationships in a small Arab town and its district. It focuses on patterns of change in the political and social makeup of the region from the period when it was virtually independent to its integration into the Hashemite Kingdom of Jordan. $£ 4.50$ Middle Eastern Monographs

\section{Arabic Literature}

H. A. R. Gibb

'It is enough to say that anyone hoping to understand the forces that have shaped the present-day Middle East must read this book.' - Middle East Journal.

Second edition 65p Oxford Paperbacks

\section{Oxford}




\section{VERÖFFENTLICHUNGEN DER GLASENAPP-STIFTUNG}

Band I. Hermann Oldenberg: Kleine Schriften. Aufsatzsammlung in zwei Teilen. Herausgegeben von Klaus L. Janert. 1967. XXXVI, IV, 1570 S., Ln. zus. DM 98,-

Band II. Helmuth von Glasenapp-Bibliographie. Bearb. von Zoltán Károlyi. 1968. XIV, 100 S., Ln. DM 28,-

Band III. Franz Kielhorn: Kleine Schriften. Aufsatzsammlung in 2 Teilen. Hrsg. von Wilhelm Rau. 1969. Teil 1: XXIV, 616 S. Teil 2: IV, 489 S., zus. Ln. DM 92,-

Band IV. Hermann Jacobi: Kleine Schriften. Hrsg. von Bernhard Kölver. 1970. Teil 1: XXIV, 546 S. Teil 2: VI, 610 S., zus. Ln. DM 98,-

Band V. Paul Thieme: Kleine Schriften. Hrsg. von Georg Buddruss. 1970. Teil 1 u. 2 zus. XX, 815 S., Ln. DM 72,-

Band VI, 1. Wilhelm Geiger: Kleine Schriften. Hrsg. von Heinz Bechert. 1973. XXXIII, 707 S., Ln. DM 72,-

Band VII. Heinrich Lüders: Kleine Schriften. Hrsg. von Oskar v. Hinüber. 1973. XVI, 561 S., 6 Abb., Ln. DM 58,-

Band VIII. Indologen-Tagung 1971. Verhandlungen der Indologischen Arbeitstagung im Museum für Indische Kunst. Berlin, 7.-9. Oktober 1971. Hrsg. von Herbert Härtel und Volker Moeller. 1973. XXI, 301 S. m. 199 Fig., 1 Farbtaf., Ln. DM 68,-

Band IX. Hans-Werbin Köhler: Srad-Dhā in der vedischen und altbuddhistischen Literatur. Hrsg. von Klaus L. Janert. 1973. XII, 76 S., Ln. DM 32,-

\section{FRANZ STEINER VERLAG GMBH WIESBADEN}

Western Germany 


\section{Journal of

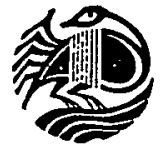 \\ Winter 1974 \\ Vol. III, No. 2}

\section{A Special Issue on the October War and Its Aftermath}

The first comprehensive analysis of the recent war to appear in English

The Egyptian and Syrian Campaigns * Arab and Israeli Reactions * Oil as a Political Weapon * The US Role * Western Europe and the Conflict *

Kissinger meets Haikal * Shazli on how Egypt crossed the Canal * Faisal and the Shah discuss Oil * Senator Fulbright on the Great Powers and the Conflict *

The Journal of Palestine Studies is the only English-language quarterly in the world dealing exclusively with the Palestine problem and the ArabIsraeli conflict.

Reviews of recent books * From the Hebrew Press * Periodicals in Review * Views from abroad * Documents and source material * Arab reports and analysis.

Annual subscription rates: US $\$ 12.00, £ 4.90$.

Student rate: US $\$ 7.00, £ 2.80$. Single copy: US $\$ 3.00, £ 1.20$

Obtainable from

The Institute for Palestine Studies

P.O. Box 7164

Beirut, Lebanon

A.S.P. Distributors

Demos

7 Bishopsthorpe Road

Grønnegade 37

London SE26 4NZ

DK-1107

England 


\section{ENGLISH TRANSLITERATION SYSTEM \\ CONSONANTS}

Column Headings: $\mathrm{A}=$ Arabic, $\mathrm{P}=$ Persian, $\mathrm{OT}=$ Ottoman Turkish, $\mathrm{MT}=$ Modern Turkish

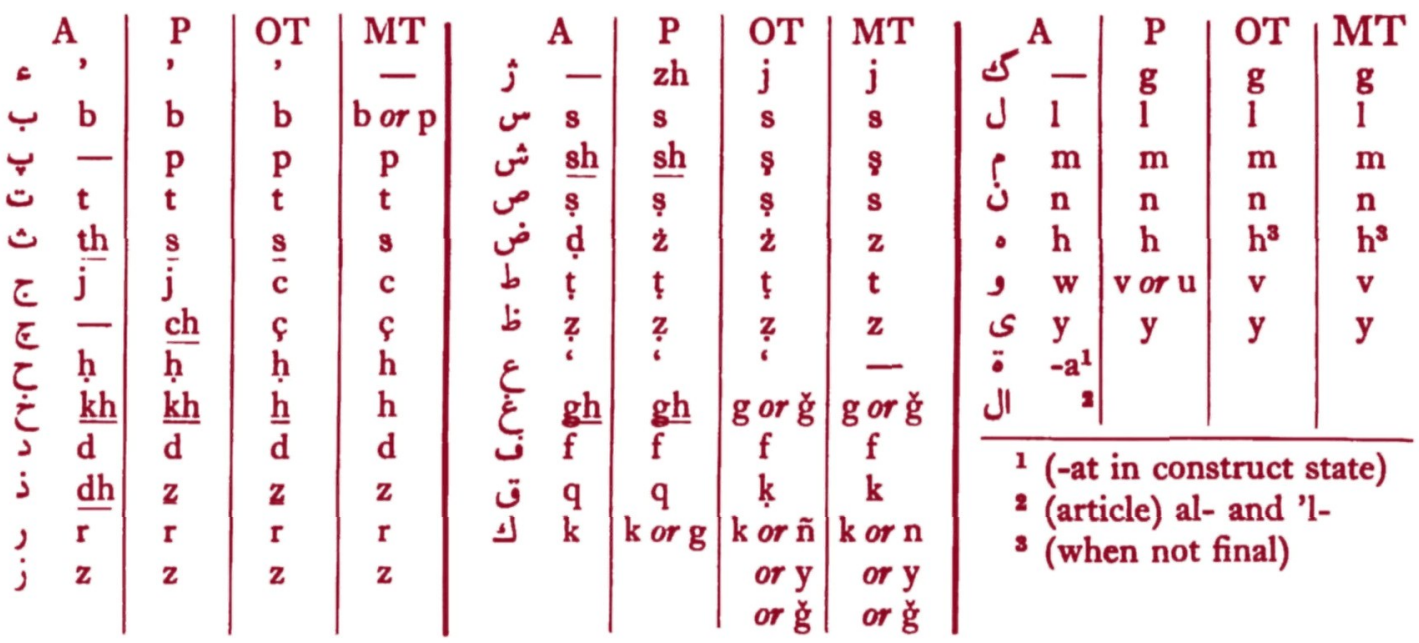

VOWELS

ARABIC AND PERSIAN

OTTOMAN TURKISH

MODERN TURKISH

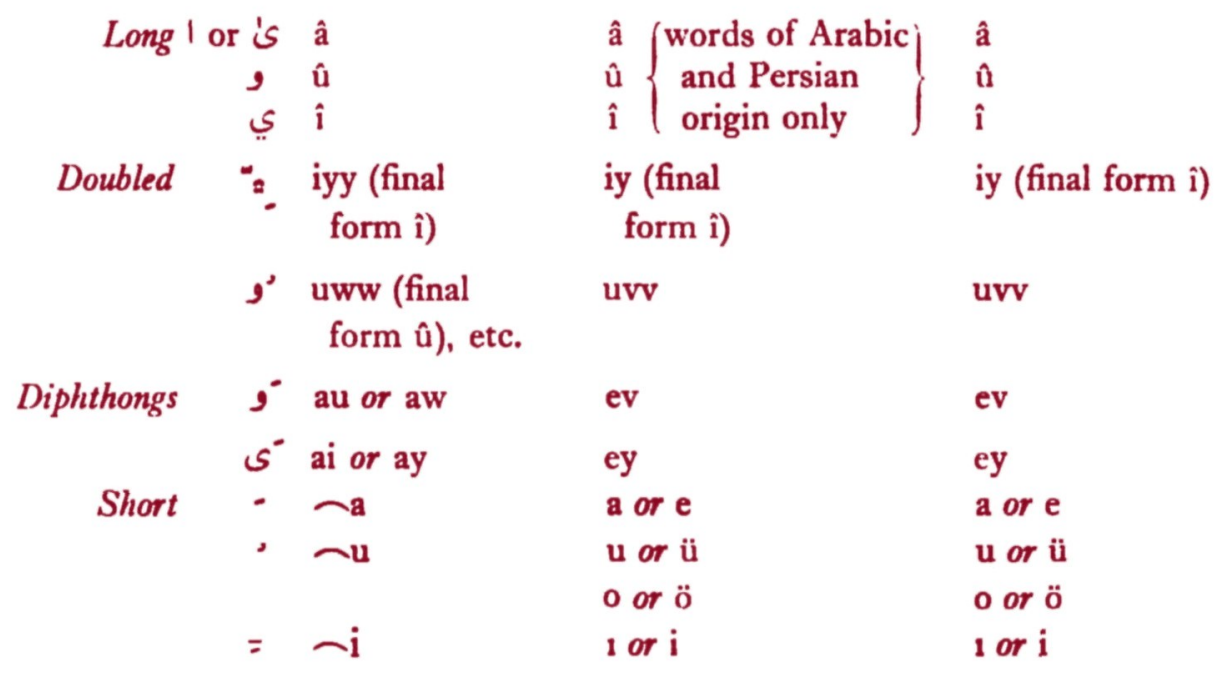

For Ottoman Turkish, authors may either transliterate or use the modern Turkish orthography. Articles submitted in French and German may be transliterated according to the systems common in those languages. 


\section{CONTENTS}

'The Enitor's Desk

pages $231-232$

Metin Ibrahim KuNt Ethnic-Regional (C'ins) Solidarity in the

Seventeenth-Cintury Ottoman Establishment

Fuad SaId Haddad An Early Arab 'Theory of Instruction

233-239

240-259

Russer. A. Stone Religious Ethic and the Spirit of Capitalism in 'Tunisia

260-273

Dale F. Eickeimax Is 'I'here an Islamic City? The Making of a Quarter in a Moroccan 'l'own

Donda Robinson I) Ivine The Modernization of Israeli Administration

Revia S. Simox The Hashemite 'Conspiracy': Hashemite Unity

'The Iranian Budgets: $1964-1970$

Khat.dun S. HesRy

'The Assyrian Affair of 1933 (II)

c) Cambridge Inniversity Pross, 1974

\section{The Middle East Studies Association of North America, Inc.}

This association was founded in 1966 in order to promote high standards of scholarship in the field of Middle Eastern studies and to facilitate communication among scholars through meetings and publications. In addition to sponsoring the fournal, which is published for the Association by the Cambridge University Press, MESA publishes a Bulletin periodically, holds an Annual Conference, and provides other professional services for its members from time to time. Enquiries concerning membership, which includes subscription to the International fournal of .Middle East Studies, should be addressed to: Headquarters and Secretariat, Middle East Studies Association, New York University, Washington Square, New York, N.Y. 10003, L.S.A. Fees are as follows: Fellows and associates, \$20.00; students, \$9.00; institutions, $\$_{30.00}$.

\section{Notes for Contributors}

Contributions and editorial correspondence should be sent to the Editor, Professor Stanford J. Shaw, Near Eastern Center, University of California, Los Angeles, California, 90024, U.S.A. Submission of an article implies that it has not been published, or is not being considered for publication elsewhere. In the intercsts of authors, copyright is normally assigned to the Cambridge University Press. Articles in English should conform with the Journal's transliteration sistem. Articles will be accepted and published in French and German, with the authors expected to follow the transliteration systems normally used in those languages. Care will be taken with manuscripts submitted, but the Editor cannot accept responsibility for any loss or damage which may take place. Contributors should keep at least one copy for use in correcting proofs. Contributors of articles and review articles receive 50 offprints. Extra copies may be purchased according to an agreed scale of charges.

\section{CAMBRIDGE UNIVERSITY PRESS}

Bentley Housc, 200 Euston Road, Iondon NW I 2DB

American Branch: 32 East 57th Street, New York, N.Y.10022

Price . 2.50 (US $\$ 6.00$ ) 1974 subscription price $f_{.7}$

(L'S $\$ 18.00$ in L.S.A. and Canadia) 